\title{
Infrared brazing of TiAl intermetallic using pure silver
}

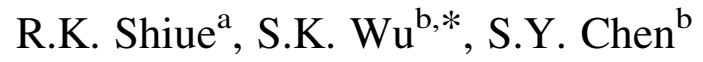 \\ a'Department of Materials Science and Engineering, National Dong Hwa University, Hualien 974, Taiwan, ROC \\ ${ }^{\mathrm{b}}$ Department of Materials Science and Engineering, National Taiwan University, Taipei 106, Taiwan, ROC \\ Available online 1 April 2004
}

\begin{abstract}
Titanium aluminides have been extensively studied due to their high specific strength and fairly good corrosion as well as oxidation resistance. The development of joining process always plays a crucial role in application of these alloys. Infrared vacuum brazing is a novel technique featured with a rapid thermal cycle. The present work reports the successful infrared brazing of TiAl using pure Ag as brazing filler metal. The transient microstructural evolution of the joint as well as its bonding strength is extensively evaluated. The infrared brazed joint is primarily comprised of Ag-rich phase solid solution with $\mathrm{Ti}$ and $\mathrm{Al}$. There are three phases in the reaction layer, including $\mathrm{Ti}(\mathrm{Al}, \mathrm{Ag})$, $\mathrm{Ti}_{3}(\mathrm{Al}, \mathrm{Ag})$ and $\mathrm{Ag}$-rich. The formation of $\mathrm{Ti}_{3} \mathrm{Al}$ in the reaction layer can be attributed to the dissolution of TiAl substrate into the Ag-rich molten braze. It is found that the Ag-rich phase dissolves much more Al than Ti. The consumption of Al can result in local enrichment of Ti atoms, so $\mathrm{Ti}_{3}(\mathrm{Al}, \mathrm{Ag})$ phase is formed. The use of pure $\mathrm{Ag}$ filler metal demonstrates excellent bonding strength of the joint. All specimens brazed at $1050{ }^{\circ} \mathrm{C}$ were fractured at TiAl substrate. Specimens brazed at $1100{ }^{\circ} \mathrm{C}$ above $60 \mathrm{~s}$ demonstrate shear strength up to $385 \mathrm{MPa}$. However, the fracture location changes from TiAl substrate into the brazement. The fracture location is either at the Ag-rich matrix or at the interface between the reaction layer and Ag-rich matrix
\end{abstract}

(C) 2004 Elsevier Ltd. All rights reserved.

Keywords: A. Titanium aluminides, based on TiAl; D. Microstructure

\section{Introduction}

The specific gravity of TiAl is about half that of Ni-based superalloys and its creep strength is also far superior to that of Al- and Ti-based alloys [1-5]. Therefore, TiAl holds out promise for use in aerospace and automobile industry [5]. TiAl alloys are the most promising alternative light-weight heat-resistant alloys, so great research efforts have been aimed at practical applications of TiAl such as turbine wheels of turbocharger, engine valves, etc. [5-7]. The successful development of various manufacturing process of TiAl alloys is very important in application of this alloy and the process of TiAl has been extensively studied in literatures [8-11]. Because the fabrication of entire assemblies from TiAl is not realistic from the standpoints of cost and reliability, limited application to the most important parts, with others being made from conventional metallic alloy(s), is the most conceivable situation for the application of TiAl [12]. Joining process inevitably plays a crucial role in using TiAl intermetallics. With regard to the

\footnotetext{
* Corresponding author. Tel.: + 886-2-2363-7846; fax: + 886-2-23634562.

E-mail address: skw@ccms.ntu.edu.tw (S.K.Wu).
}

joining of TiAl, welding, friction welding, diffusion bonding and brazing have been reported as methods for the metallurgical bonding [12-17]. The bonding of titanium aluminides is more difficult than many other engineering alloys due to the high reactivity of TiAl and the formation of brittle intermetallic phase in the joint. Consequently, the key point of joining TiAl is how to avoid and/or decrease the formation of brittle phase(s) in the joint [14].

Compared with $\mathrm{Ni}$ and Ti-based braze alloys, Ag-based braze alloys are featured with low brazing temperatures [18]. Additionally, it is reported that the use of $\mathrm{Ag}$ and Ag-based braze alloys can successfully braze most Ti alloys [15-23]. It is also noted that the TiAg intermetallics is formed during brazing. Since the TiAg compound is not brittle, the joint shows good bonding strength after brazing [20,21]. Moreover, the pure Ag can be easily applied in brazing various steels [18]. The use of pure $\mathrm{Ag}$ will be a good choice in dissimilar brazing of the Ti alloy and steel, so pure $\mathrm{Ag}$ is selected as filler metal in the study.

Brazing is one of the joining processes, which can metallurgically bond TiAl. However, traditional vacuum brazing suffered from both low production rate and high cost. Infrared vacuum brazing makes use of infrared energy generated by heating a tungsten filament in a quartz tube as 
the heating source [24-26]. The infrared rays can transmit quartz tube and be focused on the specimen. The specimen is locally heated by infrared rays and the rest of the part of the furnace is not heated during brazing process. Compared with traditional vacuum brazing, infrared brazing is a highly potential process with the characteristics of very rapid thermal cycle. The present work reports a novel approach in joining TiAl by infrared brazing using pure silver as the braze alloy. Both the microstructural evolution and shear strength of the brazed joint will be examined in order to evaluate the relation between the microstructure and shear strength of the joint.

\section{Experimental procedures}

The master alloy with the nominal composition $\mathrm{Ti}_{50} \mathrm{Al}_{50}$ (in at.\%) was prepared by vacuum arc remelting of high purity $(>99.99 \mathrm{wt} \%)$ Ti rods and Al pellets. Both Ti rods and $\mathrm{Al}$ pellets were cleaned by $1 \mathrm{HF}-15 \mathrm{HNO}_{3}-64 \mathrm{H}_{2} \mathrm{O}$ (in ml) and saturated $\mathrm{NaOH}$ solution prior to vacuum arc remelting, respectively. At least six times of vacuum arc remelting were performed and the final weight loss of the master alloy was below $0.1 \mathrm{wt} \%$. The master alloy was homogenized subsequently at $950{ }^{\circ} \mathrm{C}$ for $100 \mathrm{~h}$. Pure $\mathrm{Ag}$ foils with the thickness of $100 \mu \mathrm{m}$ were used throughout the experiment.

Compared with traditional furnace brazing, infrared brazing is featured with rapid thermal cycle. Unlike furnace brazing, higher infrared brazing temperature will do less damage to the base metal. Additionally, high brazing temperature can greatly speed up the microstructural evolution of the brazed joint. Consequently, higher brazing temperatures were chosen in the study. Infrared brazing was performed in a vacuum of $8 \times 10^{-5} \mathrm{mbar}$ and the heating rate was set at $900{ }^{\circ} \mathrm{C} / \mathrm{min}$ throughout the experiment. All specimens were preheated at $500{ }^{\circ} \mathrm{C}$ for $90 \mathrm{~s}$ before the specimens heat up to brazing temperatures. There is a time delay between the actual specimen temperature and programmer temperature, so time compensation is necessary in the experiment. The brazing time specified in the test is the actual specimen holding time in the experiment [24-26]. All process variables used in infrared brazing TiAl intermetallic are summarized in Table 1.

Table 1

Process variables used in infrared brazing of TiAl intermetallic

\begin{tabular}{llll}
\hline Brazing time (s) & $1000{ }^{\circ} \mathrm{C}$ & $1050{ }^{\circ} \mathrm{C}$ & $1100{ }^{\circ} \mathrm{C}$ \\
\hline 15 & & $\mathrm{O}$ & $\mathrm{O}$ \\
30 & & $\mathrm{O} / \Delta$ & $\mathrm{O} / \Delta$ \\
45 & & $\mathrm{O}$ & $\mathrm{O}$ \\
60 & $\mathrm{O}$ & $\mathrm{O} / \Delta$ & $\mathrm{O} / \Delta$ \\
90 & $\mathrm{O}$ & $\mathrm{O} / \Delta$ & $\mathrm{O} / \Delta$ \\
120 & $\mathrm{O}$ & $\mathrm{O} / \Delta$ & $\mathrm{O} / \Delta$ \\
180 & $\mathrm{O}$ & $\mathrm{O} / \Delta$ & $\mathrm{O} / \Delta$ \\
\hline
\end{tabular}

O, metallographic observation specimen; $\Delta$, shear test specimen.

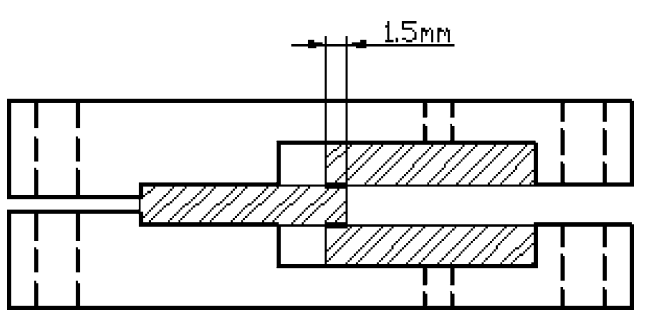

Fig. 1. A schematic diagram of the specimen used in the shear test.

The size of brazed specimens was $10.0 \mathrm{~mm} \times 10.0$ $\mathrm{mm} \times 2.5 \mathrm{~mm}$. All joined surfaces were polished by $\mathrm{SiC}$ papers up to grit 1200 and ultrasonically cleaned by acetone prior to infrared brazing. The area of filler metal was approximately the same as that of base metal. To enhance the absorption of infrared rays, a graphite fixture was used during brazing as described in previous studies [24-26]. Fig. 1 shows the schematic diagram of the specimen used in the shear test [26]. The shaded area is the TiAl base metal and the outer part of the layout is the graphite fixture used in the infrared brazing. Two bold black lines with $1.5 \mathrm{~mm}$ width in the middle of the graph is the braze alloy. The specimen was sandwiched between two graphite plates. A thermal couple was inserted into the upper graphite plate and contacted with the brazed specimen.

A shear test was performed by the Shimadzu AG-10 universal testing machine to evaluate the bonding strength of the brazed joint. The brazed specimen was compressed by a universal testing machine with a constant speed of $1 \mathrm{~mm} / \mathrm{min}$. The structure analysis of the fracture surface after shear test was performed using a Philips PW1710 $\mathrm{X}$-ray diffractometer (XRD) and $\mathrm{Cu} \mathrm{K}_{\alpha}$ was selected as the $\mathrm{X}$-ray source. The brazed sample was cut by a low-speed diamond saw and followed by a standard metallographic procedure. The cross section of the brazed specimens was examined using either LEO 1530 field emission scanning electron microscope (FESEM) or Philips XL-30 scanning electron microscope (SEM) equipped with an energy dispersive spectrometer. Quantitative chemical analysis was performed by using a JEOL JXA-8600SX electron probe microanalyzer (EPMA) equipped with a wavelength dispersive spectrometer. Its spot size is $1 \mu \mathrm{m}$ and its operation voltage is $15 \mathrm{kV}$.

\section{Results and discussion}

\subsection{Microstructural evolution of the infrared brazed TiAl/Ag/TiAl joint}

Fig. 2 shows the backscattered electron images (BEIs) of the FESEM observations for $\mathrm{TiAl} / \mathrm{Ag} / \mathrm{TiAl}$ specimen brazed at $1000{ }^{\circ} \mathrm{C}$ for various time periods. It is observed that there is a continuous reaction layer between the braze and TiAl substrate. Additionally, there are at least two phases in the reaction layer as shown in the figure. Fig. 3 displays BEIs of 


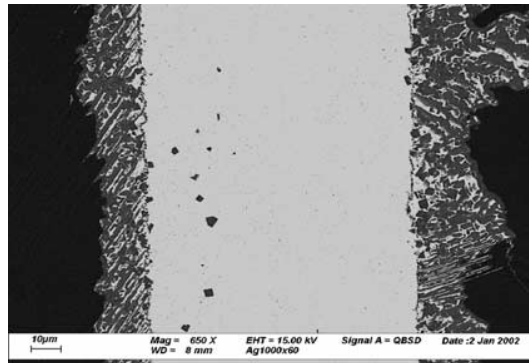

(a)

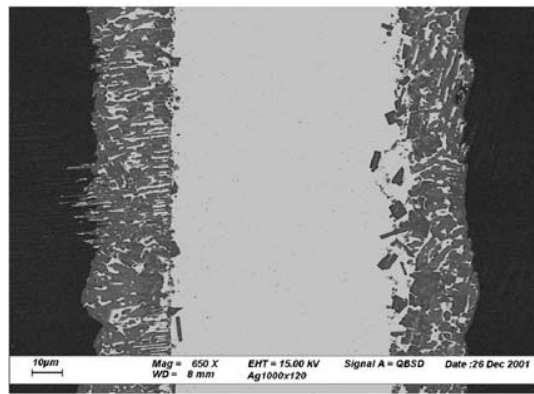

(c)

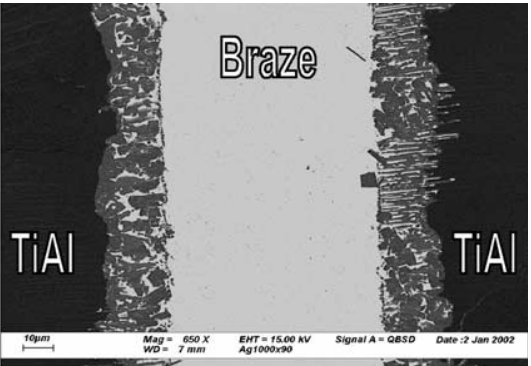

(b)

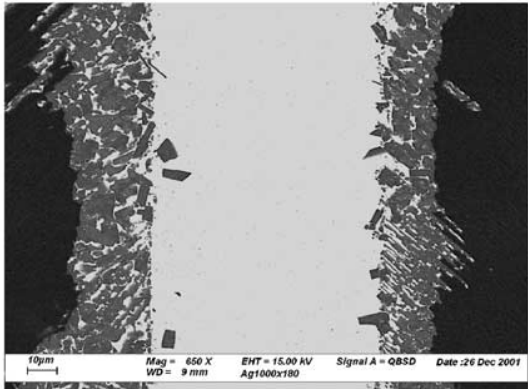

(d)

Fig. 2. The BEIs of the FESEM observations for TiAl/Ag/TiAl specimen brazed at $1000{ }^{\circ} \mathrm{C}$ for (a) 60 , (b) 90 , (c) 120 and (d) $180 \mathrm{~s}$.

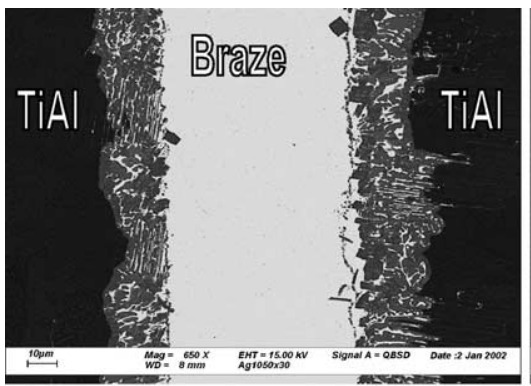

(a)

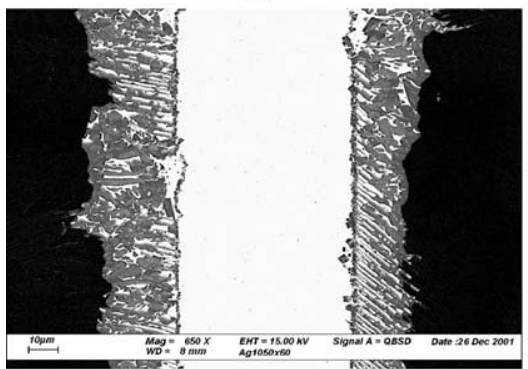

(c)

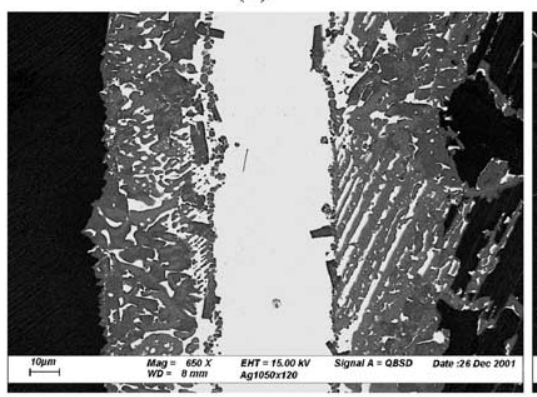

(e)

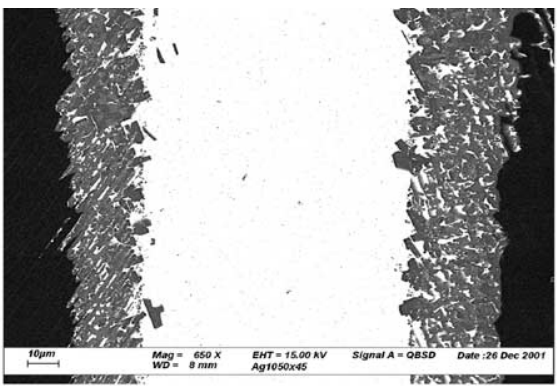

(b)

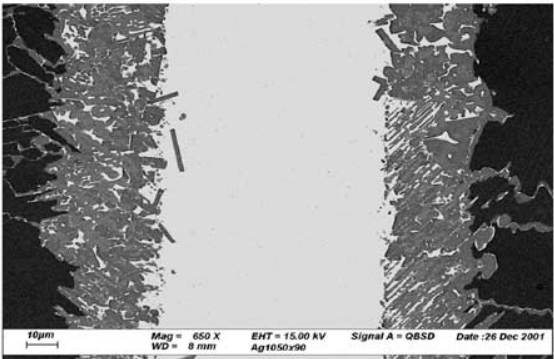

(d)

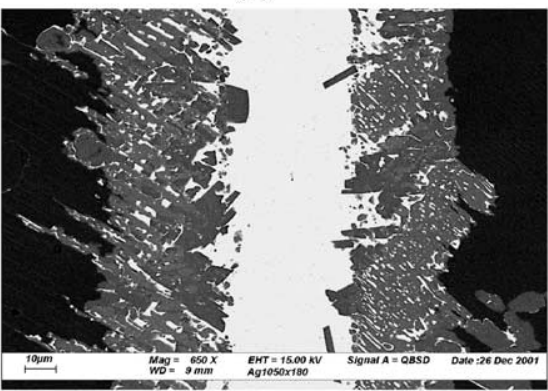

(f)

Fig. 3. The BEIs of FESEM observations for TiAl/Ag/TiAl specimen brazed at $1050{ }^{\circ} \mathrm{C}$ for (a) 30 , (b) 45 , (c) 60 , (d) 90 , (e) 120 and (f) $180 \mathrm{~s}$. 
FESEM observations for $\mathrm{TiAl} / \mathrm{Ag} / \mathrm{TiAl}$ specimen brazed at $1050{ }^{\circ} \mathrm{C}$ for $30,45,60,90,120$ and 180 s. Similar to Fig. 2, there are reaction layers between the braze and TiAl substrate, but thicker interfacial reaction layers can be found due to the higher brazing temperature. A quantitative chemical analysis was performed in order to identify various phases across the joint as shown in Fig. 4. The braze is mainly comprised of the Ag-rich phase as marked by $\mathrm{I}$ in Fig. 4. Based on the binary alloy phase diagrams, the maximum solubility of $\mathrm{Ti}$ and $\mathrm{Al}$ in $\mathrm{Ag}$ at room temperature is 2 and 11 at.\%, respectively [27]. It is also noted that the Ag-rich matrix is solid solution with both $\mathrm{Ti}$ and $\mathrm{Al}$ and their contents are close to their maximum solubility in Ag at room temperature.

According to Fig. 4, there are three phases in the reaction layer, including $\mathrm{Ti}(\mathrm{Al}, \mathrm{Ag}), \mathrm{Ti}_{3}(\mathrm{Al}, \mathrm{Ag})$ and $\mathrm{Ag}$-rich phases. According to the chemical analysis shown in the figure,
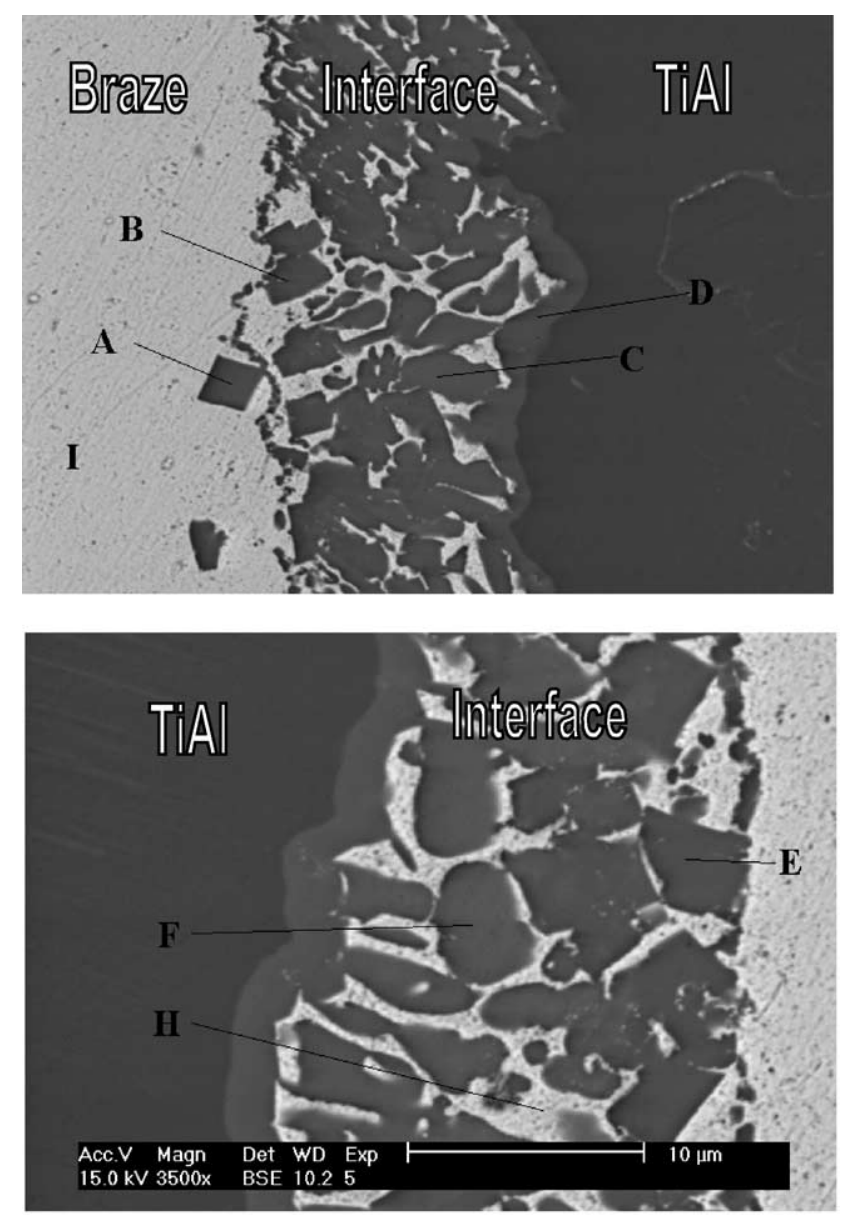

\begin{tabular}{|c|c|c|c|c|c|c|c|c|}
\hline $\mathrm{At} \%$ & $\mathrm{~A}$ & $\mathrm{~B}$ & $\mathrm{C}$ & $\mathrm{D}$ & $\mathrm{E}$ & $\mathrm{F}$ & $\mathrm{H}$ & $\mathrm{I}$ \\
\hline $\mathrm{Ti}$ & 52.5 & 52.2 & 63.1 & 63.7 & 51.8 & 66.0 & 4.8 & 0.9 \\
\hline $\mathrm{Al}$ & 43.1 & 43.5 & 33.3 & 32.4 & 43.8 & 29.7 & 7.5 & 11.9 \\
\hline $\mathrm{Ag}$ & 4.4 & 4.3 & 3.6 & 3.9 & 4.4 & 4.3 & 87.7 & 87.2 \\
\hline Phase & $\mathrm{Ti}(\mathrm{Al}, \mathrm{Ag})$ & $\mathrm{Ti}(\mathrm{Al}, \mathrm{Ag})$ & $\mathrm{Ti}(\mathrm{Al}, \mathrm{Ag})$ & $\mathrm{Ti}_{3}(\mathrm{Al}, \mathrm{Ag})$ & $\mathrm{Ti}(\mathrm{Al}, \mathrm{Ag})$ & $\mathrm{Ti}(\mathrm{Al}, \mathrm{Ag})$ & $\begin{array}{c}\mathrm{Ag}- \\
\text { based }\end{array}$ & $\begin{array}{c}\mathrm{Ag}- \\
\text { based }\end{array}$ \\
\hline
\end{tabular}

Fig. 4. The SEM BEI and EPMA chemical analysis results of TiAl/Ag/TiAl specimens brazed at $1000{ }^{\circ} \mathrm{C}$ for $60 \mathrm{~s}$.

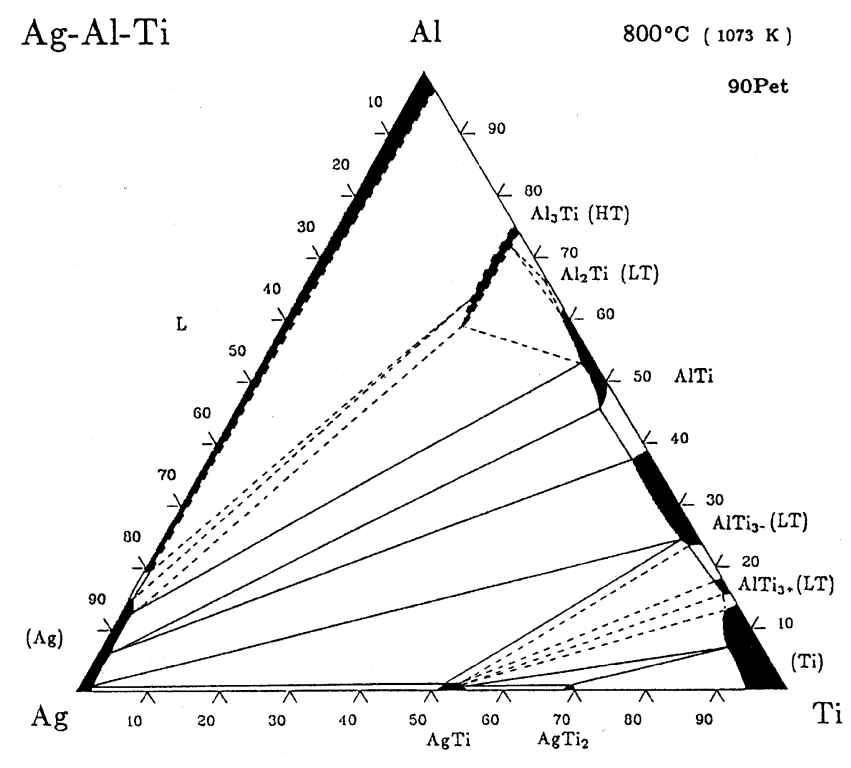

Fig. 5. The isothermal section of Ag-Al-Ti ternary alloy phase diagram at $800{ }^{\circ} \mathrm{C}[28]$.

points $\mathrm{A}, \mathrm{B}$ and $\mathrm{E}$ can be classified as $\mathrm{Ti}(\mathrm{Al}, \mathrm{Ag})$ and points $\mathrm{C}, \mathrm{D}$ and $\mathrm{F}$ are categorized as $\mathrm{Ti}_{3}(\mathrm{Al}, \mathrm{Ag})$. The Ag-rich phase solid solution with minor $\mathrm{Al}$ and $\mathrm{Ti}$ is also observed in the interfacial reaction zone as marked by $\mathrm{H}$ in the figure. A ternary alloy phase diagram will be very helpful in explanation of the phase evolution across the brazed joint. Fig. 5 shows the isothermal section of $\mathrm{Ag}-\mathrm{Al}-\mathrm{Ti}$ ternary alloy phase diagram at $800{ }^{\circ} \mathrm{C}$ [28]. There is a composition triangle among $\mathrm{TiAl}, \mathrm{Ti}_{3} \mathrm{Al}$ and $\mathrm{Ag}$-rich phases. Based on Fig. 5, the Ag-rich phase can dissolve more Al than Ti at $800{ }^{\circ} \mathrm{C}$. Additionally, the solubility of $\mathrm{Ag}$ in both TiAl and $\mathrm{Ti}_{3} \mathrm{Al}$ is below 5 at.\%. It is consistent with our experimental observations.

The formation of $\mathrm{Ti}_{3} \mathrm{Al}$ in the reaction layer can be attributed to the dissolution of TiAl substrate into the Ag-rich molten braze. It is found that the Ag-rich phase dissolves much more $\mathrm{Al}$ than $\mathrm{Ti}$ as demonstrated in Fig. 5. The consumption of $\mathrm{Al}$ can result in local enrichment of $\mathrm{Ti}$ atoms, so $\mathrm{Ti}_{3}(\mathrm{Al}, \mathrm{Ag})$ phase is formed after infrared brazing. Based on Fig. 5, the $\mathrm{Ti}$ content in $\mathrm{TiAl}$ phase ranges between 38 and 53 at.\% and the Ti content in $\mathrm{Ti}_{3} \mathrm{Al}$ phase ranges between 60 and 76 at.\%. The solubility of $\mathrm{Ag}$ in both TiAl and $\mathrm{Ti}_{3} \mathrm{Al}$ phase is below 5 at. $\%$. It is in accordance with our analysis results. Fig. 6 displays the liquidus projection of $\mathrm{Ag}-\mathrm{Al}-\mathrm{Ti}$ ternary alloy phase diagram and some important invariant reactions are also included [28]. The primary fields of $(\mathrm{Ag}), \mathrm{TiAl}$ and $\mathrm{Ti}_{3} \mathrm{Al}$ are in contact, so there is a specific invariant reaction $\mathrm{U}_{5}$ observed in the figure. The $\mathrm{U}_{5}$ invariant reaction can be expressed as $\mathrm{L}+\mathrm{AlTi}_{3} \leftrightarrow(\mathrm{Ag})+\mathrm{AlTi}$. TiAl, $\mathrm{Ti}_{3} \mathrm{Al}$ and Ag-rich phases are found in the experiment. As discussed earlier, the initial dissolution of TiAl substrate into molten Ag-rich braze results in both the formation of $\mathrm{Ti}_{3} \mathrm{Al}$ interfacial layer 


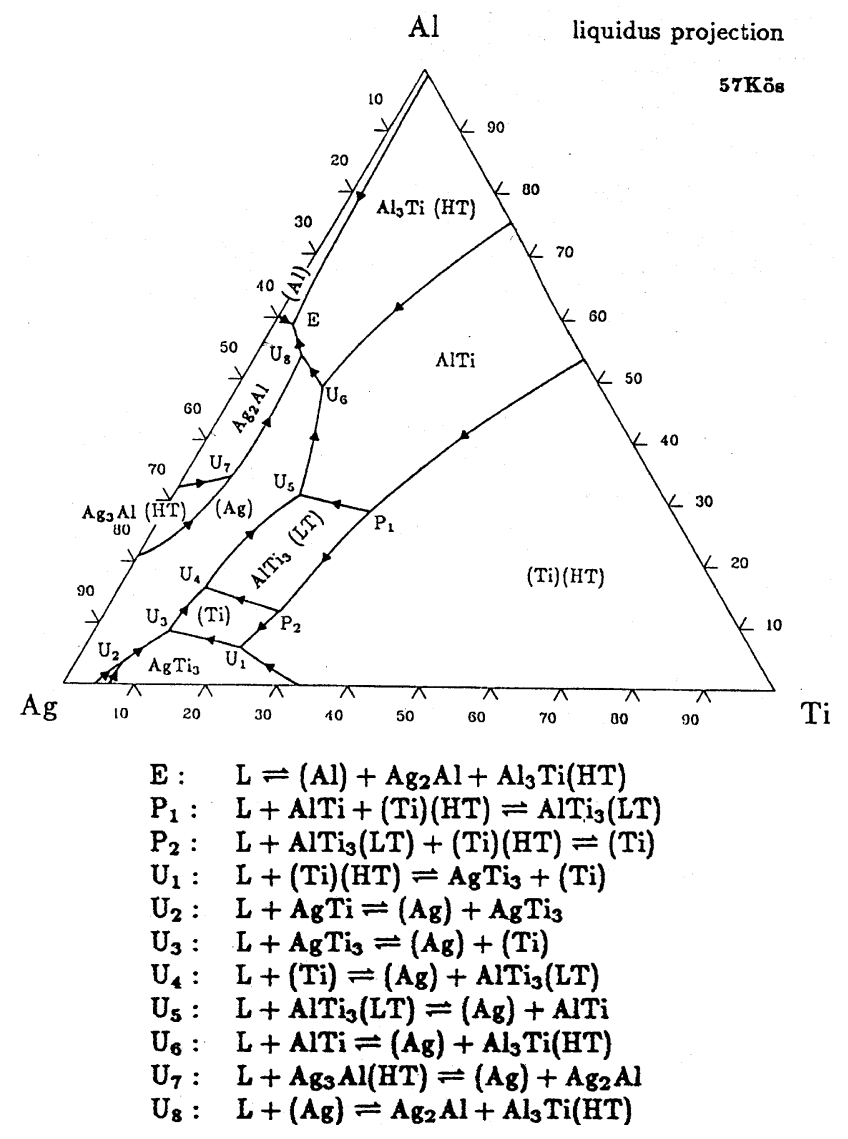

Fig. 6. The liquidus projection of $\mathrm{Ag}-\mathrm{Al}-\mathrm{Ti}$ ternary alloy phase diagram [28].

and local enrichment of $\mathrm{Al}$ content in the Ag-rich molten braze. The formation of continuous interfacial $\mathrm{Ti}_{3}(\mathrm{Al}, \mathrm{Ag})$ layer can be evidenced by Fig. 4 (marked by D). Therefore, the interfacial reaction zone is consisted of $\mathrm{Ti}(\mathrm{Al}, \mathrm{Ag})$, $\mathrm{Ti}_{3}(\mathrm{Al}, \mathrm{Ag})$ and Ag-rich phase and its thickness is increased with increasing brazing temperature and/or time.

Fig. 7 shows both SEM BEI and EPMA chemical analysis results of $\mathrm{TiAl} / \mathrm{Ag} / \mathrm{TiAl}$ specimens brazed at $1100{ }^{\circ} \mathrm{C}$ for $180 \mathrm{~s}$. The width of Ag-rich braze as marked by $\mathrm{B}$ in the figure is greatly decreased due to the higher brazing temperature. Analagous to the previous result, the interface is mainly composed of $\mathrm{Ti}(\mathrm{Al}, \mathrm{Ag})$ and $\mathrm{Ti}_{3}(\mathrm{Al}, \mathrm{Ag})$ phase as marked by $\mathrm{C}$ and $\mathrm{D}$, respectively. Different from the specimen brazed at $1050{ }^{\circ} \mathrm{C}$, the amount of Ag-rich phase in the interface is greatly decreased. Additionally, there is a new phase found in the figure. The stoichiometry of the new phase as marked by $\mathrm{A}$ in Fig. 7 is close to $\mathrm{Ti}(\mathrm{Al}, \mathrm{Ag})_{3}$ and the $\mathrm{Ti}(\mathrm{Al}, \mathrm{Ag})_{3}$ phase can also be observed in the isothermal section of $\mathrm{Ag}-\mathrm{Al}-\mathrm{Ti}$ phase diagram (Fig. 5). In Fig. 6, the invariant reaction at point $\mathrm{U}_{6}$ can be expressed as $\mathrm{L}+\mathrm{AlTi} \leftrightarrow(\mathrm{Ag})+\mathrm{Al}_{3} \mathrm{Ti}$. The reaction scheme from $U_{5}$ to $U_{6}$ results in forming $\mathrm{Ti}(\mathrm{Al}, \mathrm{Ag})_{3}$ phase. Therefore, it is reasonable to observe $\mathrm{Ti}(\mathrm{Al}, \mathrm{Ag})_{3}$ phase in the brazement.

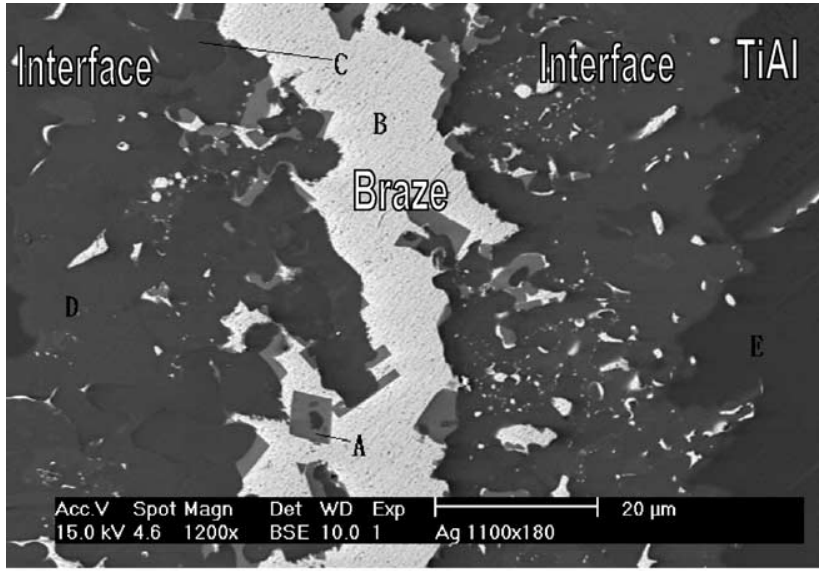

\begin{tabular}{|c|c|c|c|c|c|}
\hline $\mathrm{Wt} \% / \mathrm{At} \%$ & $\mathrm{~A}$ & $\mathrm{~B}$ & $\mathrm{C}$ & $\mathrm{D}$ & $\mathrm{E}$ \\
\hline $\mathrm{Ti}$ & $27.0 / 26.4$ & $0.2 / 0.5$ & $60.1 / 51.2$ & $66.5 / 58.8$ & $63.6 / 49.6$ \\
\hline $\mathrm{Al}$ & $32.2 / 55.9$ & $2.9 / 10.5$ & $29.8 / 45.0$ & $23.9 / 37.4$ & $36.3 / 50.3$ \\
\hline $\mathrm{Ag}$ & $40.8 / 17.7$ & $96.9 / 89.0$ & $10.1 / 3.8$ & $9.6 / 3.8$ & $0.1 / 0.1$ \\
\hline $\mathrm{Phase}$ & $\mathrm{Ti}(\mathrm{Al}, \mathrm{Ag})_{3}$ & $\begin{array}{c}\text { Ag-rich } \\
\text { matrix }\end{array}$ & $\mathrm{Ti}(\mathrm{Al}, \mathrm{Ag})$ & $\mathrm{Ti}_{3}(\mathrm{Al}, \mathrm{Ag})$ & $\begin{array}{c}\text { TiAl } \\
\text { substrate }\end{array}$ \\
\hline
\end{tabular}

Fig. 7. The SEM BEI and EPMA chemical analysis results of TiAl/Ag/TiAl specimens brazed at $1100{ }^{\circ} \mathrm{C}$ for $180 \mathrm{~s}$.

\subsection{Mechanical evaluation of the infrared brazed TiAl/Ag/TiAl joint}

Table 2 summarizes the shear test results of $\mathrm{TiAl} / \mathrm{Ag} /$ TiAl joint infrared brazed at 1050 and $1100{ }^{\circ} \mathrm{C}$. All specimens brazed at $1050{ }^{\circ} \mathrm{C}$ were fractured at TiAl substrate. It demonstrates excellent bonding strength of the joint. For specimens brazed at $1100{ }^{\circ} \mathrm{C}$ below $60 \mathrm{~s}$, the fracture location is the same as specimens brazed at $1050{ }^{\circ} \mathrm{C}$. However, the fracture location changes from base metal into the brazement as increasing the brazing time above $60 \mathrm{~s}$. To facilitate failure analysis, all fractured specimens were subsequently mounted in an epoxy and their cross sections were examined by SEM. Fig. 8 shows the cross section of $\mathrm{TiAl} / \mathrm{Ag} / \mathrm{TiAl}$ joint after the shear test for specimens infrared brazed at $1100{ }^{\circ} \mathrm{C}$ for 90,120 and $180 \mathrm{~s}$. The fracture appears at the interface between the reaction layer and Ag-rich braze for the specimen brazed at $90 \mathrm{~s}$ as shown in Fig. 8(a). It is observed that cracks initiate at the interface and propagate into the TiAl

Table 2

Summary of shear test results for $\mathrm{TiAl} / \mathrm{Ag} / \mathrm{TiAl}$ joint

\begin{tabular}{lll}
\hline Time (s) & Temperature & \\
\cline { 2 - 3 } & $1050{ }^{\circ} \mathrm{C}$ & $1100{ }^{\circ} \mathrm{C}$ \\
\hline 30 & Fracture of TiAl substrate & Fracture of TiAl substrate \\
60 & Fracture of TiAl substrate & Fracture of TiAl substrate \\
90 & Fracture of TiAl substrate & $372 \mathrm{MPa}$ \\
120 & Fracture of TiAl substrate & $385 \mathrm{MPa}$ \\
180 & Fracture of TiAl substrate & $348 \mathrm{MPa}$ \\
\hline
\end{tabular}




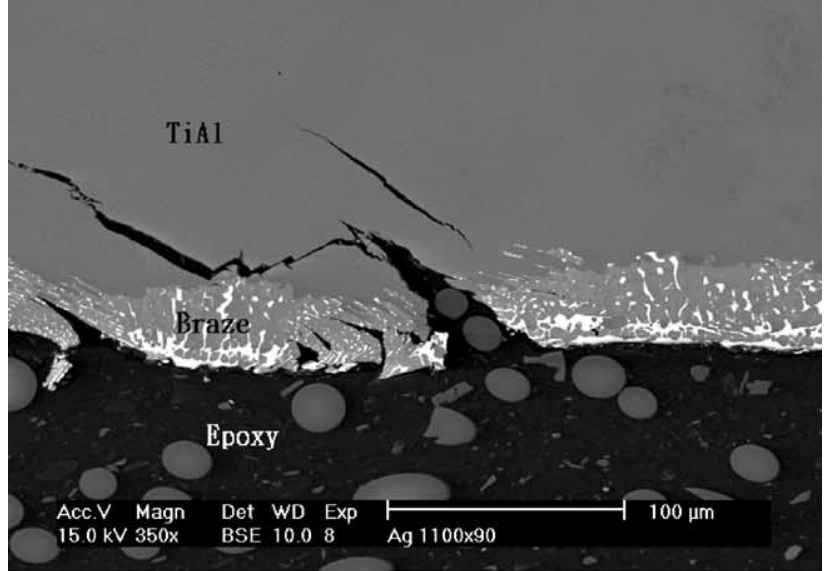

(a)

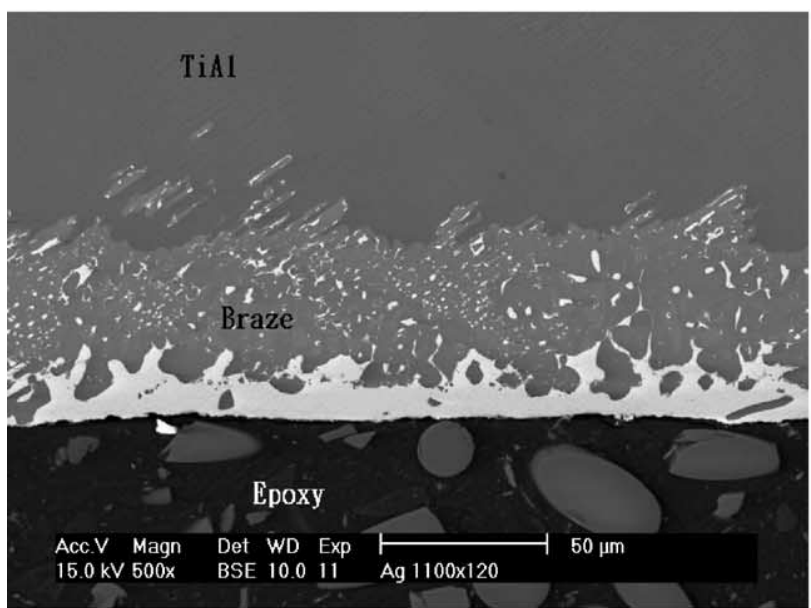

(b)

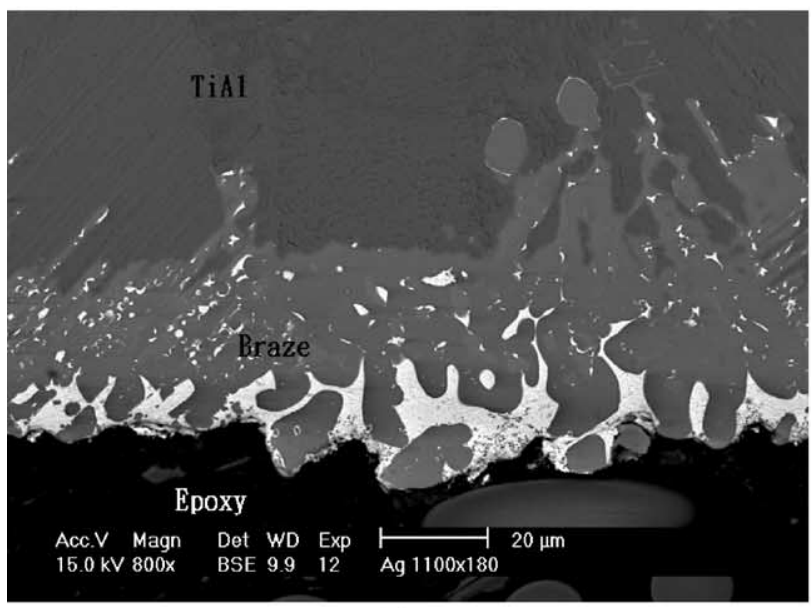

(c)

Fig. 8. Cross section of TiAl/Ag/TiAl joint after shear test infrared brazed at $1100{ }^{\circ} \mathrm{C}$ for (a) 90 , (b) 120 and $180 \mathrm{~s}$.

substrate. The location of fracture changes into Ag-rich matrix as the brazing time increases to $120 \mathrm{~s}$ and the Agrich braze was sheared in the test as shown in Fig. 8(b). For the specimen brazed at $180 \mathrm{~s}$, the fracture location is at the interface between the reaction layer and Ag-rich

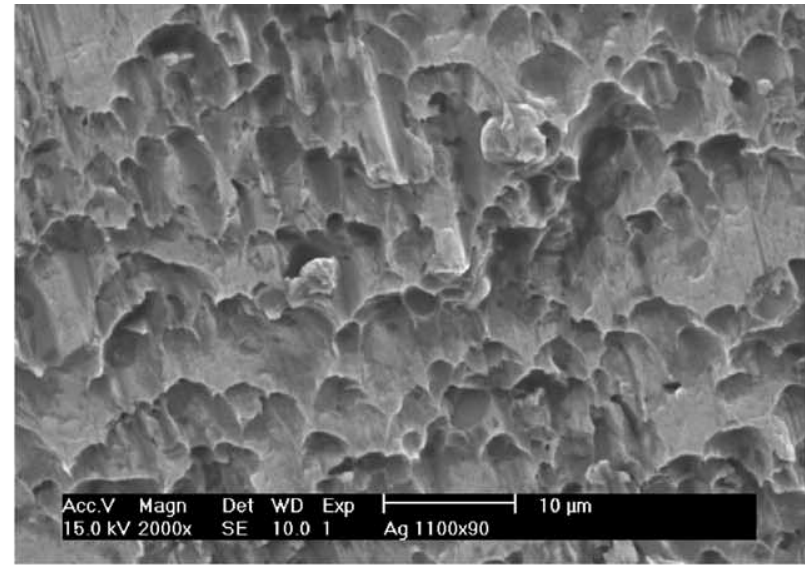

(a)

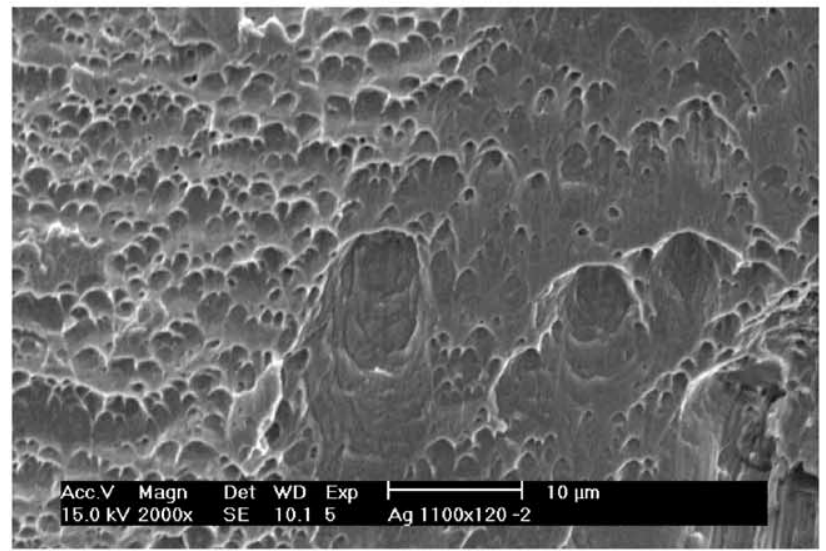

(b)

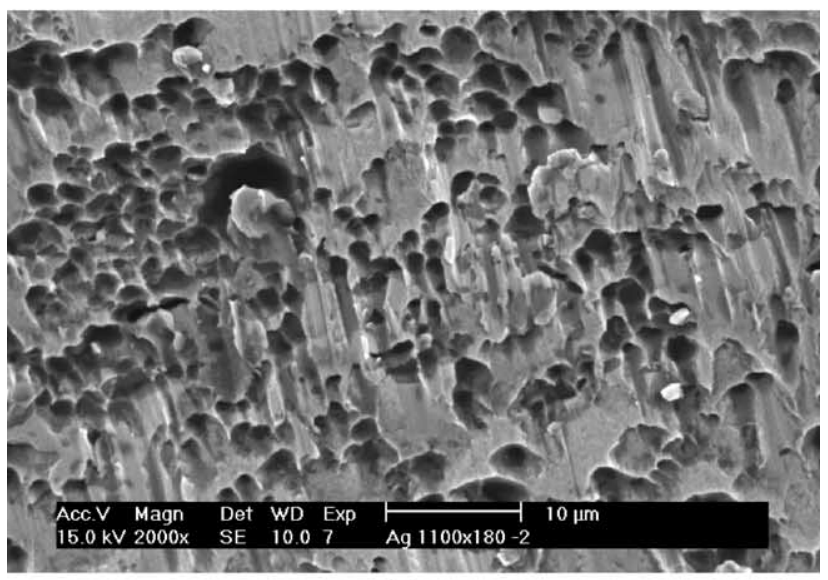

(c)

Fig. 9. Fractographs of TiAl/Ag/TiAl joint after shear test infrared brazed at $1100{ }^{\circ} \mathrm{C}$ for (a) 90 , (b) 120 and $180 \mathrm{~s}$.

matrix (Fig. 8(c)). Fig. 9 shows fractographs of $\mathrm{TiAl} / \mathrm{Ag} /$ TiAl joint after shear test infrared brazed at $1100{ }^{\circ} \mathrm{C}$ for 90, 120 and $180 \mathrm{~s}$. Since the Ag-rich braze failed for specimens brazed at $120 \mathrm{~s}$, the fractograph demonstrates extensive dimple fracture as shown in Fig. 9(b). However, quasi-cleavage fracture was observed for specimens brazed at 90 and $180 \mathrm{~s}$ as shown in Fig. 9(a) and (c). 

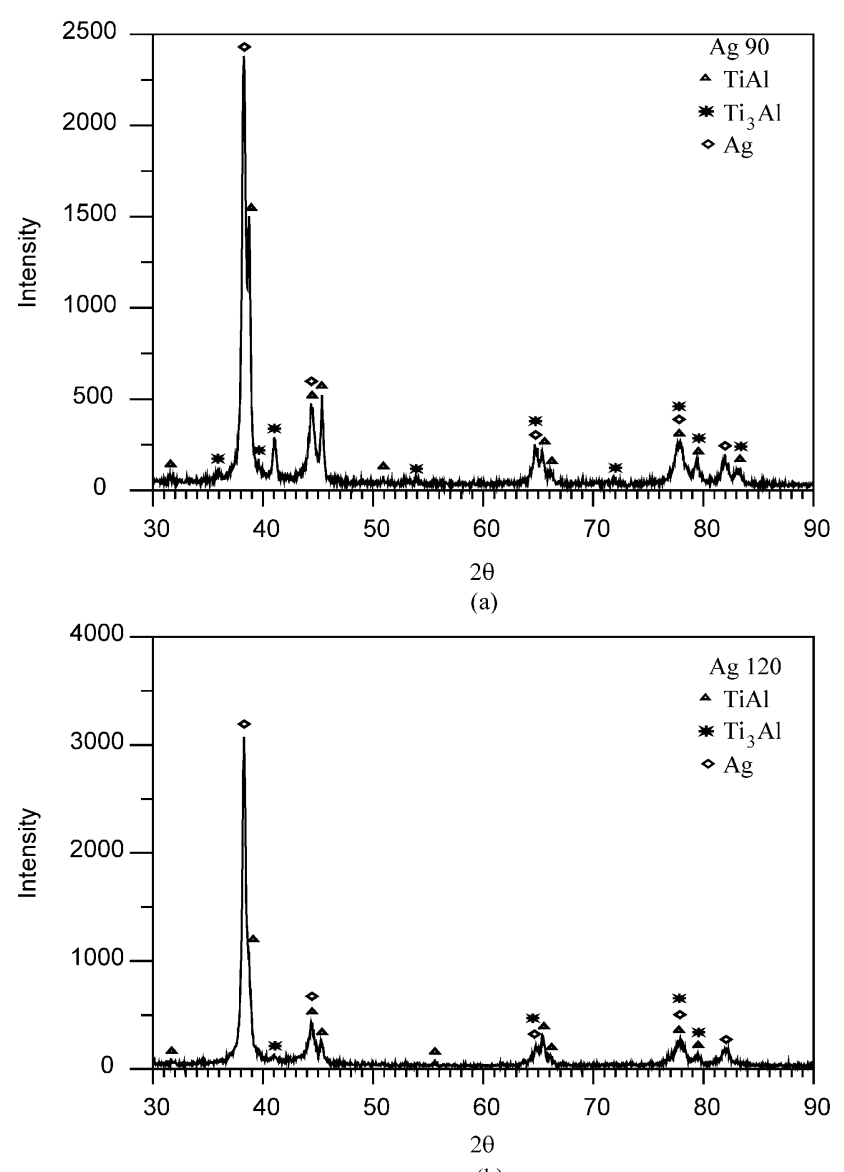

(b)

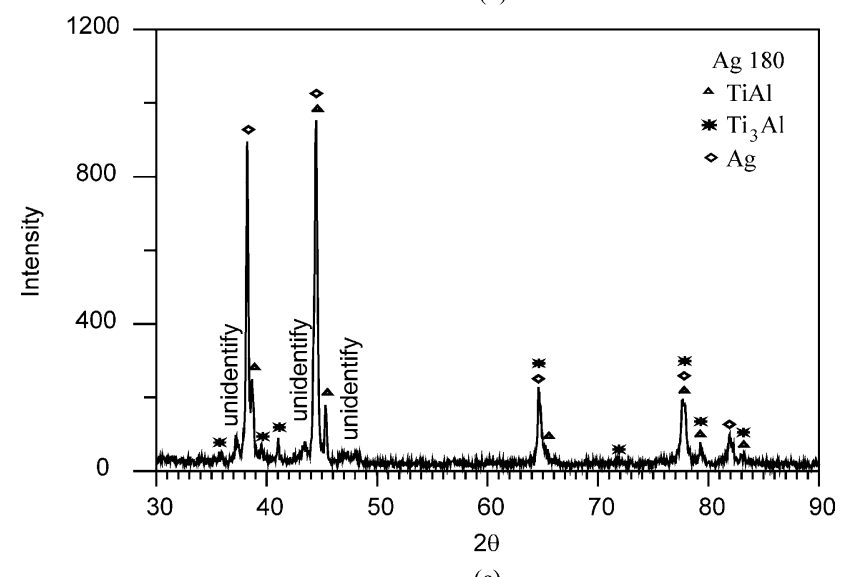

(c)

Fig. 10. XRD of the fracture surface after shear test for specimens infrared brazed at $1100{ }^{\circ} \mathrm{C}$ for (a) 90 , (b) 120 and (c) $180 \mathrm{~s}$.

It is caused by the interfacial fracture close to the reaction layer. Unlike the ductile fracture of Ag-rich matrix, very limited plastic deformation was experienced in the reaction layer.

Fig. 10 shows XRD of the fractured surface after shear test for specimens infrared brazed at $1100{ }^{\circ} \mathrm{C}$ for 90,120 and $180 \mathrm{~s}$. In Fig. 10(a), $\mathrm{TiAl}, \mathrm{Ti}_{3} \mathrm{Al}$ and $\mathrm{Ag}$ phases are found in the fractured surface. It is consistent with the SEM observation as shown in Fig. 8(a). Cracks initiate at the interface between the reaction layer and braze and propagate into the TiAl substrate. As described earlier, the reaction layer contains $\mathrm{Ti}_{3}(\mathrm{Al}, \mathrm{Ag}), \mathrm{Ti}(\mathrm{Al}, \mathrm{Ag})$ and $\mathrm{Ag}$-rich phases, so all three phases demonstrate strong XRD peaks in the analysis. Different from Fig. $10(\mathrm{a}), \mathrm{Ti}_{3}(\mathrm{Al}, \mathrm{Ag})$ phase shows very weak XRD peaks in Fig. 10(b). The fracture location is not nearby the interface but the Ag-rich matrix for the specimen brazed at $120 \mathrm{~s}$. The fracture surface is primarily comprised of $\mathrm{Ag}$, so the signal of $\mathrm{Ti}_{3} \mathrm{Al}$ phase is very weak. Finally, $\mathrm{Ti}_{3} \mathrm{Al}$ XRD peaks are observed in Fig. 10(c) for the specimen brazed at $180 \mathrm{~s}$. It is caused by the interfacial fracture of the infrared brazed specimen due to the rapid growth of the reaction layer. All XRD structure analyses provide experimental support of the above microstructural observations across the joint.

\section{Conclusions}

The microstructural evolution of infrared brazing TiAl intermetallic using pure Ag as filler metal is evaluated in the experiment. Both microstructural evolution and shear strength of the infrared brazed joint are extensively examined and important conclusions are summarized as below.

1. The brazed joint mainly consists of Ag-rich matrix alloyed with both $\mathrm{Ti}$ and $\mathrm{Al}$ and the Ag-rich phase dissolves much more $\mathrm{Al}$ than $\mathrm{Ti}$. There are three phases in the reaction layer, including $\mathrm{Ti}(\mathrm{Al}, \mathrm{Ag}), \mathrm{Ti}_{3}(\mathrm{Al}, \mathrm{Ag})$ and Ag-rich phases. The thickness of the reaction layer is increased with increasing brazing temperature and time.

2. The formation of $\mathrm{Ti}_{3} \mathrm{Al}$ in the reaction layer can be attributed to the dissolution of $\mathrm{TiAl}$ substrate into the Agrich molten braze. It is found that the Ag-rich phase dissolves much more $\mathrm{Al}$ than $\mathrm{Ti}$. The consumption of $\mathrm{Al}$ can result in local enrichment of $\mathrm{Ti}$ atoms, so $\mathrm{Ti}_{3}(\mathrm{Al}, \mathrm{Ag})$ phase is formed.

3. The use of pure Ag filler metal demonstrates excellent bonding strength exceeding $385 \mathrm{MPa}$. All specimens brazed at $1050{ }^{\circ} \mathrm{C}$ were fractured at $\mathrm{TiAl}$ substrate. For specimens brazed at $1100{ }^{\circ} \mathrm{C}$ below $60 \mathrm{~s}$, the fracture location is the same as the specimen brazed at $1050{ }^{\circ} \mathrm{C}$. However, the fracture location changes from TiAl substrate into the brazement as the brazing time increases above $60 \mathrm{~s}$. The fracture location is either at the Ag-rich matrix or at the interface between the reaction layer and Ag-rich matrix.

\section{Acknowledgements}

The authors gratefully acknowledge the financial support from National Science Council (NSC), Republic of China, under the grants NSC 89-2216-E002-071. 


\section{References}

[1] Liu CT, Maziasz PJ. Intermetallics 1998;6:653.

[2] Liu CT, Schneibel JH, Maziasz PJ, Wright JL, Easton DS. Intermetallics 1996;4:429.

[3] Kainuma R, Fujita Y, Mitsui H, Ohnuma I, Ishida K. Intermetallics 2000;8:855.

[4] Soboyejo WO, Lou K. Scripta Metall 1993;29:1335.

[5] Tetsui T, Ono S. Intermetallics 1999;7:689.

[6] Noda T. Intermetallics 1998;6:709.

[7] Dimiduk DM, Miracle DB, Ward CH. Mater Sci Technol 1992;8:367.

[8] Ye HQ. Mater Sci Engng 1999;A263:289.

[9] Matsugi K, Hatayama T, Yanagisawa O. Intermetallics 1999;7:1049.

[10] Wu GQ, Huang Z. Scripta Mater 2001;45:895.

[11] Yoo MH, Zou J, Fu CL. Mater Sci Engng 1995;A192-3:14.

[12] Tetsui T. Intermetallics 2001;9:253.

[13] Holmquist M, Recina V, Pettersson B. Acta Metall Mater 1999;47:1791.

[14] Blue CA, Warrier SG, Robson MT, Lin RY. Weld J 1993;6:51.

[15] Noda T, Shimizu T, Okabe M, Iikubo T. Mater Sci Engng 1997; A239-40:613.
[16] Blue CA, Blue RA, Lin RY. Process Adv Mater 1994;9:141.

[17] Nakao Y, Shinozaki K, Hamada M. ISIJ Int 1991;31:1260.

[18] Olson DL, Siewert TA, Liu S, Edwards GR, ASM handbook, vol. 6. Materials Park, USA: ASM International; 1993.

[19] Humpston G, Jacobson DM. Principles of soldering and brazing. Metals Park, USA: ASM International; 1993.

[20] Dececco NA, Parks JN. Weld J 1953;32:1071.

[21] Tiner NA. Weld J 1955;34:846.

[22] Kaarlela WT, Margolis WS. Weld J 1974;53:629.

[23] Wantanabe T, Higo Y, Miki T, Yanagisawa A. Q J Jpn Weld Soc 1994;12:502.

[24] Shiue RK, Wu SK, O JM, Wang JY. Metall Mater Trans 2000;31A: 2527.

[25] Yang TY, Wu SK, Shiue RK. Intermetallics 2001;9:341.

[26] Shiue RK, Wu SK, Hung CM. Metall Mater Trans A 2002;33A: 1765.

[27] Massalski TB. Binary alloy phase diagrams. Materials Park, USA: ASM International; 1990.

[28] Villars P, Prince A, Okamoto H. Handbook of ternary alloy phase diagrams. Metals Park, USA: ASM International; 1995. 